\begin{tabular}{|l|l|}
\hline Postprint Version & 1.0 \\
\hline Journal website & http://vb23.bsl.nl/frontend/index.asp?custom_product id=1388- \\
\hline Pubmed link & $\underline{ }$ \\
\hline DOI & \\
\hline
\end{tabular}

This is a NIVEL certified Post Print, more info at http://www.nivel.eu

\title{
Onderzoek voor en na rampen
}

\author{
JORIS IJZERMANS* \\ * NIVEL, Utrecht \\ Dr. C.J. IJzermans, NIVEL, Postbus 1568, 3500 BN Utrecht, e-mail: j.yzermans@nivel.nl
}

Het opzetten en uitvoeren van onderzoek naar de gezondheid van mensen na een ramp is door het ministerie van VWS goed geborgd. Wetenschappelijk onderzoek over (de kwaliteit van) de voorbereiding op rampen ontbreekt grotendeels en dat geldt ook voor evaluatieonderzoek waardoor er te weinig wordt geleerd van opgedane ervaringen.

\section{ONDERZOEK NA RAMPEN}

Een ramp kent verschillende verschijningsvormen. Voor onderzoek naar mogelijke rampgerelateerde gezondheidsproblemen is daarbij vooral van belang of het om een plotselinge gebeurtenis gaat, of om een sluipende. Het meest voorkomende type wordt ‘flitsramp' genoemd: transportongeval (Vliegramp Bijlmermeer), ontploffing (Vuurwerkramp Enschede) of brand (Nieuwjaarsbrand Volendam). Pandemieën, zoönosen en sommige milieu-incidenten zijn meestal van het sluipende type. Ook is belangrijk of een ramp mensen treft die in eenzelfde gemeenschap wonen of mensen die zich toevallig op eenzelfde plaats bevinden. De drie voorbeelden betroffen mensen binnen één gemeenschap. Bij een groot treinongeluk of de uitbraak van de veteranenziekte in Bovenkarspel komen de getroffenen overal vandaan.

In de nasleep van de Bijlmerramp heeft het ministerie van VWS drie pijlers voor nazorg van rampen geformuleerd die vervolgens na de Vuurwerkramp werden toegepast: het opzetten van een gemeentelijk Informatie- en Adviescentrum, het verlenen van integrale psychosociale zorg en het uitvoeren van gezondheidsonderzoek. De laatste pijler werd in Enschede vormgegeven door onderzoekers van het NIVEL, RIVM, GGD Twente en Instituut voor Psychotrauma. Zij onderzochten de getroffenen en de ingezette hulpverleners (drie metingen met vooral vragenlijsten) en maakten gebruik van bestaande registratiesystemen, met name die van huisarts en bedrijfsarts. In het vijfde jaar na de ramp bood de opdrachtgever de onderzoekers de gelegenheid om de gegevens te ontsluiten voor het wetenschappelijke veld: die geste resulteerde in ruim 30 internationale publicaties. Over het uitvoeren van dit type langjarig onderzoek, over implementatie en uitvoering van de 3 pijlers van VWS en over (de effecten van) het leveren van regelmatige feedback aan zorgverleners werd veel geleerd

\section{ADVIES OVER ONDERZOEK}

Rampen worden gekenmerkt door chaos. Op GGD-en bestaat vaak een te kleine staf om grootschalig wetenschappelijk gezondheidsonderzoek na een (flinke) ramp in de regio alleen op te zetten en uit te voeren. Onderzoekers van de gevolgen van rampen zijn vaak passanten; in Nederland heeft slechts een enkeling zich erin gespecialiseerd. Mede daarom besloot het ministerie van VWS om het RIVM opdracht te geven een centrum in te stellen van waaruit aan het openbaar bestuur geadviseerd kan worden of gezondheidsonderzoek plaats moet vinden en bij een positief advies welk type onderzoek. Het centrum voor gezondheidsonderzoek na rampen (CGOR) werd opgericht en is inmiddels opgegaan in het centrum voor Gezondheid \& Milieu. Advies wordt gegeven door een expertgroep van vertegenwoordigers van relevante disciplines. Gezondheidsonderzoek na rampen is inmiddels geborgd in de Wet Publieke Gezondheid. Van iedere GGD wordt verwacht zich hierop voor te bereiden. 
Recent is het GROP verschenen, het GGD rampen opvangplan, waarin wordt uitgewerkt wat de taken zijn als er een ramp plaatsvindt. Eén van deze taken betreft het doen opzetten van wetenschappelijk gezondheidsonderzoek.

\section{ONDERZOEK OVER DE VOORBEREIDING OP RAMPEN}

Het uitvoeren van onderbouwend onderzoek over (de kwaliteit van) de voorbereiding op rampen en over de geleerde lessen is nog niet goed ontwikkeld. De staven van regionale GHOR bureaus zijn klein en bestaan uit praktijkmensen. De prioriteit ligt bij de operationele uitvoering en alle zeilen moeten worden bijgezet om de positie in het (virtuele) veld te vestigen of te onderhouden.

Het adagium is dat als er maar goed wordt opgeleid, getraind en geoefend (OTO) en de leerstof aansluit op de reguliere zorg, het allemaal wel goed zal gaan op het 'gouden uur'. Dat blijkt steeds weer opnieuw niet over de gehele linie mee te vallen.

Voor de ziekenhuizen is een belangrijke impuls uitgegaan van de verplichting een Ziekenhuis rampen opvangplan (ZiROP) op te stellen. Samenwerking van GHOR met huisartsen is nog erg pril: pas recent verscheen een handreiking OTO.

En als er dan onderzoek wordt uitgezet betreft het de structuur, nauwelijks het proces en vrijwel nooit de inhoud. Er is soms wel 'best practice', maar men werkt te weinig 'evidence based'. Een complicatie hierbij is dat de GHOR alleen coördineert en niet zelf bij de daadwerkelijke zorg is betrokken. Er wordt met regelmaat gevraagd om prestatie-indicatoren, terwijl de inhoud niet goed is beschreven en de prestatie derhalve alleen diffuus of juist te precies kan worden geformuleerd.

Momenteel wordt overwogen of een Academische Werkplaats Crisisbeheersing in de OGZ zinvol zou kunnen zijn. Die vraag zal positief beantwoord moeten worden, waarbij erop zal moeten worden toegezien dat het voorgenomen wetenschappelijk onderzoek nu eens niet alleen de structuur betreft. Zo moet niet worden onderzocht of er een gewondenkaart aanwezig is, maar hoe die (nationaal en internationaal) wordt gebruikt en waarom de praktijk steeds niet goed lukt. Er zou toegewerkt moeten worden naar een uniforme registratie van getroffenen, niet alleen voor verwanten, maar ook voor diensten in de nazorg; een ramp houdt zich zelden aan de gemeentegrens. Ander punt van onderzoek is het longitudinaal in kaart brengen van de gang door de gezondheidszorg van een getroffene, inclusief de follow-up van het handelen op de rampplek door omstanders en door professionals. Bovenal is onderzoek van belang naar het steeds maar falen in de praktijk van de communicatie en informatieverstrekking tussen participanten. 